\title{
Research that counts: OECD statistics and 'policy entrepreneurs' impacting on Australian adult literacy and numeracy policy
}

\begin{abstract}
This paper analyses research that has impacted on Australia's most recent national policy document on adult literacy and numeracy - the National Foundation Skills Strategy (NFSS). The paper draws in part on Lingard's 2013 paper entitled 'The impact of research on education policy in an era of evidence-based policy' in which he outlines the distinction between research for and of policy. The former is privileged in education policy formation and comprises largely statistical evidence (i.e. 'policy as numbers') often drawing on the globalised authority of organisations such as the OECD, along with research commissioned by policy makers and undertaken by 'policy entrepreneurs'. Research of policy represents academically oriented research, which is often qualitative, seeks new knowledge, and may challenge the status quo. Through an analysis of studies cited in and thus impacting on the NFSS, we detail the main authors of research for policy and indicate their ideological commitment to the neoliberal agenda that now dominates the adult literacy and numeracy field in Australia and other OECD countries. Research of policy in this context has had little policy impact, but is nevertheless promoted by the authors as a means of countering the current reductionist discourses of adult literacy and numeracy reflected in national policy.
\end{abstract}

Key words: literacy, numeracy, educational research, education policy

\section{Introduction}

This paper focuses on research that has impacted on the most recent national policy document on adult literacy and numeracy in Australia, the National Foundation Skills Strategy (NFSS, see Standing Council on Tertiary Education, Skills \& Employment [SCOTESE] 2012). While in a technical sense there are differences between a strategy and a policy, with the former associated more with the 'means' of effecting policy, the NFSS can be incorporated within a broader view of educational policy described by Luke $(2003,132)$ as 'bids to centrally regulate and govern flows of discourse, fiscal capital, physical and human resources across the time and space boundaries of educational systems'. Our aim is to demonstrate, and offer an explanation of why it is that particular types of research have an impact on this national strategy. The research we analyse comprises the studies referenced in the strategy in the form of footnotes in the 30 page document.

We draw heavily on Lingard's (2013) analysis of 'The impact of research on education policy in an era of evidence-based policy' in which, referring to previous research (e.g. Gordon, Lewis and Young 1977), he makes the 'classic distinction' between research for policy, and research of policy. As he explains, and as we demonstrate in relation to the NFSS, research for policy is privileged in educational policies. It is research underpinned largely by quantitative data - statistics (i.e. 'policy as numbers', see Lingard 2011), and commissioned 
research undertaken by 'policy entrepreneurs' designed to address a particular problem - in the case of this paper, low literacy among Australian adults. Lingard (2013, 119) describes policy entrepreneurs as 'those who make a living doing research for policy within agencies set by governments or international organisations or whatever commissioning agency'. This follows Ball's $(2006,61)$ explanation that policy entrepreneurs are 'committed to the application of certain technical solutions to organisations and contexts which are taken $a$ priori to be in need of structural and/or cultural change'. Usually their interests are bound up with the success of their research. Lingard $(2013,119)$ views research for policy 'as operating an "engineering" relationship between research and policy', which usually takes the policy problem as given, and provides legitimation for a particular policy direction designed to alleviate the problem. Levin $(2005,622)$ in a discussion of research-policy relationships explains this process as follows: 'Solutions are advanced by the same set of actors who try to define problems. In fact, much of the promotion of problems is done in order to generate support for policy solutions'. Research of policy on the other hand, is usually more academically oriented, which seeks new knowledge and understandings. It may involve qualitative methodologies, and rather than taking the problem as given, it may deconstruct or problematise the problem.

Predominantly the focus of the policy work of Lingard and others (e.g. Lingard 2010, 2011, 2013; Lingard, Martino and Rezai-Rashti 2013; Rizvi and Lingard 2010; Sellar and Lingard 2013 ) is on critical analyses of educational policy relating to the schooling sector. Our paper represents an additional though related case study of educational policy involving the adult literacy and numeracy sector, and while policy in this sector has recently been the subject of academic debates involving a number of OECD countries (e.g. Atkinson 2012; Grek 2013; Hamilton 2011, 2012; Hamilton and Pitt 2011; Hamilton, Maddox and Addey 2015; Jablonka 2015; Tsatsaroni and Evans 2014), to date these debates have extended only marginally to the Australian adult literacy and numeracy policy context (see Black and Yasukawa 2014a, 2014b). It has been more than a decade, marked by Lo Bianco and Wickert's (2001) edited volume on policy activism, since adult literacy and numeracy policy in Australia has been subject to any sustained academic analysis.

Before detailing aspects of the research/educational policy nexus, however, we need to be clear that research is $a$ contributing factor among a range of others in the formation of national policies. Lo Bianco $(2001,13)$ for example, in describing the language and literacy policy trends in Australia from the late 1960s to the early 2000s, indicates the complex relative impact of language professionals (the intellectual legitimation), local ethnic and community groups (the political constituency), commercial and trade factors (the economic imperative), and from the 1990s, the discourse of 'English literacy as human capital', which adds further to the economic imperative. Research plays a role in all these factors, especially in the latter which we expand on in this paper, but overriding all of them, as Lingard (2013; Rizvi and Lingard 2010) reminds us, is politics - the role of ideology. Thus, while policy involves the allocation of resources, it is also about the allocation of values, and a question to be addressed in this paper is whose values? And how does research in the Australian adult literacy and numeracy policy context fit with these values? 


\section{The research/educational policy nexus: neoliberalism and the OECD}

To establish the broader parameters of our paper, we begin with Allan Luke's $(2010,178)$ encapsulation of the predominant trends in the use of research evidence for current education policy. He states:

Over the last decade, the most debilitating and effective mythology about educational research is a binary distinction: between qualitative 'critical work' which has been portrayed as scientifically 'soft', politically correct and ideological by the press, politicians and educational bureaucrats - and empirical, quantitative scientific research, which is presented as unbiased, truthful and the sole grounds for rational policy formation.

Luke laments the continuing insistence by policy makers on the use of 'evidence-based' research, representing the latter in the above binary distinction, which he sees as very narrow measures in educational domains, and which serves to reinforce existing inequalities in schooling. He argues instead for 'a broad, rich, multidisciplinary, quantitative and qualitative, generalizable and local canvas of research data and findings' (179) to inform policy.

A driving force behind the privileging of evidence-based research for educational policy formation is neoliberalism, which can be broadly defined as 'the agenda of economic and social transformation under the sign of the free market' (Connell 2013, 100). In recent decades the market logic of this form of advanced capitalism has 'cascaded' to all levels of education - schools, universities and vocational/technical education, in all western nations to the extent that, according to Connell (2013, 109): 'Neoliberal politicians, businessmen, measurement experts, economists and education system managers now form the arena in which education policy is made'. In a similar way Ball $(2012,4)$ refers to 'roll-out' neoliberalism.

This cascading or roll-out of neoliberal influence in educational policies, at least in the past two decades, is due in large part to the global influence of the Organisation for Economic Cooperation and Development (OECD). According to Sellar and Lingard (2013, 711), the OECD 'has taken on a more significant policy actor role, supplanting popular conceptions of it as merely a "think tank" supporting the interests of rich nations'. Lacking any direct leverage over the economies of western nations, the OECD assumes indirect global influence through its 'mode of soft governance' (711), including the development of networks of 'epistemic communities of policy analysis' (712) that involve policy analysts, bureaucrats and politicians within the OECD and in member countries. Grek (2013) adds to this analysis by examining the processes through which the OECD has gained transnational consensus for its educational discourses in Europe, indicating the impact of multiple networks and meetings of like-minded experts, statisticians and national policymakers.

The OECD's influence in educational policy derives largely from its role in developing a series of international surveys measuring mainly literacy and numeracy skills (i.e. the 
International Adult Literacy Survey - IALS; Programme for International Student Assessment - PISA; the Adult Literacy and Life Skills - ALL; and most recently the Programme for the International Assessment of Adult Competencies - PIAAC). These surveys, and the research associated with them (e.g. Coulombe, Tremblay and Marchland 2004), have linked educational levels, and literacy and numeracy in particular, with human capital development. Literacy and numeracy levels have become, in effect, proxies for measuring the economic development and international competitiveness of nations. Thus educational policy framed according to these levels has become 'economised' (Lingard, 2010, 136). The notion of comparison has been crucial for the success of the OECD, as the survey results enable the ranking and ordering of nations according to how their school-aged or adult populations fare in these surveys. This often leads to 'gap talk' (Lingard 2011, 355) and a discourse of crisis in the educational policy responses of national governments who fear the implications of poor survey results for their global economic competitiveness.

The global authority of the OECD and the scale and international promotion of their surveys at transnational government levels have served to legitimise the OECD's definition of literacy and numeracy skills, how these skills are measured, their link with workplace learning and productivity, and the representation of these skills as '... almost the sine qua non of living' in high achieving societies (Grek 2013, 700). Measuring literacy and numeracy according to the OECD's definitions and understandings has heralded a new era of psychometric testing which dominates national educational regimes, including for example, NAPLAN (National Assessment Program - Literacy and Numeracy) testing in Australian schools (see Lingard, 2010). And in the Australian vocational education and training (VET) sector comprehensive and standardised literacy and numeracy testing based on OECD measures is currently being promoted (Australian Workforce and Productivity Agency 2013). In other countries such as Canada, OECD survey data are similarly transposed into curriculum for use in adult literacy programmes (Pinsent-Johnson 2015), though interestingly, Scotland, with its existing 'social practices' literacy policy, has 'for the time being' resisted the influence of OECD measures (Tett 2014, 139).

OECD survey statistics steering national educational policies at a distance have been termed 'policy as numbers' (Lingard 2011), and these statistics represent essentially the research that counts in the policy context in this paper, or as Lingard $(2011,372)$ notes, 'what is counted is what counts' as numbers have become the technology of governance. They form the central element of research for policy.

\section{Literacy as numbers}

Recent academic debates on adult literacy policy in the UK and also Canada and Scotland focus on the dominant role of OECD statistics (e.g. Gardner et al. 2010), and has led to recent discussion of 'literacy as numbers' (Hamilton, Maddox and Addey 2015). Hamilton (2001, $2011,2012,2014)$ in particular has demonstrated how the OECD's statistics and conceptual understandings of literacy in its international surveys (which apply also to numeracy) privilege one form of literacy at the expense of others, which is then translated into national 
policy in the UK. The media is seen to play a significant mediating role in this process as it does in other national contexts (for example, in Canadian adult literacy policy, see Walker and Rubenson 2014, and in the reporting of PIAAC in France and Japan, see Yasukawa and Evans 2015). Critiques of the dominant role of the OECD in national adult literacy and numeracy policy making by Hamilton and others (e.g. Hamilton and Barton 2000; Jackson 2005; Rubenson and Walker 2011; Street 1998) focus largely on the failure of international surveys to properly account in a meaningful way for how literacy and numeracy practices are used in local sites. In other words, there is a significant mismatch, or 'gap' between the 'standardisations and normalisations' of policy and the 'messy, lived practices of those who are the targets of policy' (Jackson, 2005, 769 citing Kell 2001). This 'gap', which is quite different to the 'gap talk' mentioned earlier in relation to skill deficits, mirrors the differences between research for and research of policy which we explore later in this paper in relation to the NFSS in Australia.

According to some researchers (e.g. Atkinson 2012, Black and Yasukawa 2014b), the dominance of OECD statistics on adult literacy and numeracy policy, and in particular the establishment and international acceptance of standards for functioning or participating in society (i.e. 'level 3'), has led to the negative labelling and the social control of marginalised people. Street (2011) argues that international organisations such as the OECD and also UNESCO (United Nations Educational, Scientific and Cultural Organization) manage to dominate policy agendas in adult literacy precisely because they have the organisational power to name and define the field.

\section{The Australian policy context - The ALLP as a forerunner}

The focus of this paper is the NFSS, the first major policy initiative in Australian adult literacy and numeracy in over 20 years, since the Australian Language and Literacy Policy (ALLP - see Department of Employment, Education and Training [DEET] 1991). This paper is not the place for a critique of the ALLP beyond what has already been documented quite extensively (e.g. Lo Bianco and Wickert 2001). However, as background to discussions of the NFSS, it may be useful to outline some elements of the ALLP which resonate with points made so far in this paper. Numbers, for example, feature prominently in the 'clear and compelling' case made for action on adult literacy (DEET 1991, 2). The ALLP states: 'approximately one million Australian adults have literacy problems which prevent them from participating effectively in the workforce, in education and training, and in community life' (ibid.). This one million is an extrapolation from statistics in Wickert's (1989) No single measure, the first national survey of adult literacy in Australia. The OECD also appears to play a role, but not in providing statistics at this stage, rather in an ideological sense with their concern over skill levels that 'would have begun to filter onto the desks of senior bureaucrats and politicians before 1990' (Wickert 2001, 78). The ALLP is a policy with a strong human capital rationale, with, for example, its direct linking of low levels of literacy with high levels of unemployment (DEET 1991), and its funding of LLN (language, literacy and numeracy) programmes for jobseekers and workers. Lo Bianco $(2001,27)$ refers to the governing political party ideology of the time as '... free market thinking'. The research 'that 
counts' in the ALLP can be seen to be commissioned largely by the government of the day, but importantly, the agenda was driven in part by professionals in the adult literacy field acting as policy activists (Wickert 2001), and significant research at the time of the ALLP was undertaken primarily within the higher education academy. This research included the first national survey of adult literacy in Australia (Wickert 1989), a study of the attitudes and opinions of unions and employers to literacy in the workplace (Long 1989), and an evaluation of LLN in labour market programmes (Cumming and Morris 1991). According to Wickert $(2001,77)$, these projects had 'a profound impact on policy development in the field'.

Despite the 20 year hiatus between the ALLP and the NFSS, the latter in many respects can be seen as an extension of the former, especially in relation to its human capital rationale. But before considering the NFSS in detail there are some broader policy perspectives we should consider in relation to VET policy, because currently, and for the past 40 years since the Kangan Report (Australian Committee on Technical and Further Education 1974), adult literacy and numeracy have been largely embedded in the VET system. Adult literacy and numeracy programmes initially represented 'lifelong education' values which combined with training values (skills) in the new technical and further education (TAFE) system that the Kangan Report created (see Ryan 2011). However, the ALLP in 1991, in the wake of national policy statements on the need for Skills for Australia (Dawkins and Holding 1987), and the beginnings of a training reform agenda, brought adult literacy and numeracy programmes strongly within the training values of VET, and over the next 20 years adult literacy and numeracy programmes have become increasingly vocationalised. Recent VET policy in Australia has been subject to similar dominant OECD discourses (Legrand and Vas 2014) to those outlined earlier in this paper which have influenced adult literacy policy. So much so that recent major VET policy reports (e.g. Skills Australia 2010) tend to conflate adult literacy and numeracy almost completely with workforce skills development. Thus the NFSS can be seen to represent not just adult literacy and numeracy policy, but VET policy, especially as it relates to workforce development. These shifts have seen authorship of the policy research 'that counts' increasingly located within policy entrepreneurs representing business and industry.

\section{The National Foundation Skills Strategy (NFSS) for adults - research impacts}

The NFSS was officially launched on 28 September 2012 at an electronics factory in South Australia. The NFSS is a much shorter document than the ALLP, and also, unlike the ALLP, it does not relate specifically to the schooling sector or languages other than English. Importantly, however, it adds a further dimension to adult literacy and numeracy with its definition of 'foundation skills', which includes English language, literacy and numeracy (LLN) and 'employability skills, such as collaboration, problem solving, self-management, learning and information and communication technology (ICT) skills required for participation in modern workplaces and contemporary life' (SCOTESE 2012, 2). While there are some broad references in the strategy to the role of literacy and numeracy in contemporary life, including social inclusion, engaging with the community, and better health and families, overwhelmingly the strategy focuses on employment and the human capital 
implications of improved literacy and numeracy. In view of this policy bias, our responses in this paper will focus primarily on the economistic aspects.

The strategy document comprises 30 pages, with a Foreword by the then Minister for Tertiary Education, Skills, Science and Research, Christopher Evans. There is a two-page Executive Summary followed by four chapters: Chapter 1: The case for a National Foundation Skills Strategy for Adults; Chapter 2: National Foundation Skills Strategy for Adults; Chapter 3: National priority areas for foundation skills; Chapter 4: Actions for national priority areas. The document concludes with two Appendices and a Glossary. There is no separate References section, rather, there are 39 numbered footnotes within the main text that feature references to publications that substantiate or expand on claims made in the strategy.

The two-page Executive Summary sets the scene, and begins by making the case for the strategy. There are three research references in the footnotes of this section and they indicate a research trend that continues throughout the document. After defining what is meant by foundation skills the strategy (SCOTESE 2012, 2) states:

People with higher LLN skills are more likely to be employed, participate in their community, experience better health and engage in further training.

This statement is referenced in a footnote to 'Skills Australia (2010) Australian Workforce Futures'. The beginning of the next paragraph in the Executive Summary (ibid.) then states:

A move from low-skilled work to greater knowledge-based work has increased the need for workers with good LLN skills.

The corresponding footnote reference for this statement is: 'Industry Skills Councils (2011) No more excuses'. The summary then leads into the evidence that Australian adults have a problem with LLN, and the strategy (ibid.) states:

... findings from the 2006 Adult Literacy and Life Skills (ALLS) survey revealed that 44 per cent of Australia's working age population (around 6 million people) have literacy levels below Level 3; that is, the level needed to meet the complex demands of work and life in modern economies.

The footnote reference for this statement is: 'Australian Bureau of Statistics (2006) Adult Literacy and Life Skills Survey: Summary Results'.

These three references are telling of the research generally that impacts on the NFSS, and their organisational affiliations require a brief explication. Skills Australia was established by the federal government in 2008 as a statutory agency providing advice to the government on Australia's current, emerging and future workforce skills and development needs. Later, in 2012 it became the Australian Workforce and Productivity Agency, though to maintain the direct policy link in this paper, we will continue to refer to it as Skills Australia. The second organisation, Industry Skills Councils (ISC), represents eleven industry sectors and is also funded by the federal government with a mission that includes working with industry to develop nationally recognised vocational education and training. Both Skills Australia and 
the Industry Skills Councils would clearly fit within Lingard's $(2013,119)$ explanation of policy entrepreneurs as 'those who make a living doing research for policy within agencies set by governments ...'. Strictly speaking, however, these agencies undertake little research themselves, rather, they analyse existing research through their own organisational prisms, and use it to make strong policy advocacy claims. The cited publication Skills Australia's (2010) Australian workforce futures for example, devotes a section on 'Improving language, literacy and numeracy skills' (35-42), drawing on selected national and international research studies. The section concludes with recommended actions that include comments such as: 'It is imperative that there is a renewed national leadership in focusing efforts in raising the level of our language, literacy and numeracy skills' (41) and 'there is a need to radically upscale the national effort in LLN training' (42). Similarly, the ISC (2011) publication No more excuses, is a collection of research findings and industry reports and quotes assembled to make a cogent argument for a particular policy direction. The title itself makes a strong advocacy claim, and the publication specifically proposes that 'the Council of Australian Governments should establish an overarching blueprint for action on LLN in Australia 20122022' (49) and that the ISCs 'urge governments and training providers to continue to acknowledge the importance and urgency of lifting LLN levels, and to work together with ISCs to act on these proposals' (49).

In advocating for policy and funding for adult LLN, both the Skills Australia and ISC reports, along with the NFSS strategy itself, rely primarily on the third reference mentioned in the Executive Summary - 'Australian Bureau of Statistics (2006) Adult literacy and Life Skills Survey: Summary Results'. This publication is the linchpin of the NFSS, providing quite literally the 'research that counts'. Without its numbers/statistics, indicating the extent of the problem of literacy and numeracy in the Australian adult population, it is difficult to see how the government (and the above policy advocacy agencies) could make a strong case for the NFSS. The Adult Literacy and Life Skills Survey (ALL) is an OECD/Statistics Canada survey conducted in a wide range of OECD countries, with the first results published in 2005 (see OECD/Statistics Canada 2005), and the Australian results first published by the Australian Bureau of Statistics (ABS) in 2006. Statistics from this ABS publication are outlined at the beginning of chapter one of the NFSS to make 'the case' for policy action. The NFSS (SCOTESE 2012, 4) states:

The 2006 ALLS survey found that 40 per cent of employed Australians, 60 per cent of unemployed Australians and 70 per cent of those not in the labour force have a literacy level and/or numeracy level below the level needed to meet the complex demands of work and life in modern economies.

To reinforce the legitimacy of this criterion level (level 3) for functioning in modern life, reference is made to another footnote which states:

Skill level 3 on the ALLS scale is considered by the Council of Australian Governments (COAG) to be the minimum level required by individuals to meet the complex demands of work and life in modern economies 
Thus, level 3 literacy and numeracy in the ALL findings (the international literature refers mainly to acronym ALL rather than ALLS), which is used to indicate whether people can or cannot function properly in society, and which is adopted by the country's peak intergovernmental forum $\mathrm{COAG}$, derives directly from the OECD. We should not underestimate the importance of the ALL survey in the NFSS; it is the primary source of the statistical evidence that the adult population has a problem with literacy and numeracy that needs to be addressed by a strategy. For dramatic visual effect, the strategy provides these statistics in diagrammatic form (5) extrapolating from the ALL findings the numbers of Australian adults affected by low LLN - those below level 3, showing for example, 4,567,240 people i.e. 40 per cent of those employed, and 371,280 people i.e. 60 per cent of those unemployed.

After making the statistical case, the strategy in two pages (6-8) indicates the benefits of improved LLN to individuals, employers and the economy, and compares Australia with other countries, in particular, New Zealand. These sub sections of the strategy draw on most of the footnotes in the strategy - 19 of the total of 39. In these footnotes, four of them refer again to the same Skills Australia (2010) publication, and three to the same ISC (2011) publication, highlighting their significant impact on the strategy. In the section on 'the benefits to individuals' the ALL data play a key role in one of the references to the work of another government-funded agency, the Productivity Commission (2010), which statistically claims a link between improved literacy and numeracy levels on the ALL and employment outcomes such as labour force participation and hourly wage rates. In the next section on 'benefits to employers' the strategy (6) states: 'Australian Industry Group research found that 75 per cent of respondents to a national employer survey reported that their business was affected by low levels of literacy and numeracy'. This quote is then footnote referenced to an Australian Industry Group 2010 publication Employer views on workplace literacy and numeracy skills, their impact on business and the most effective measures for improving skills. The Australian Industry Group (AIG) is a peak industry association representing and advocating for the interests of a considerable number of businesses across all sectors of the economy (60,000 according to the AIG's website at http://www.aigroup.com.au/). Not surprisingly, the starting point/rationale for the AIG's (2010) study is the reported ALL findings that 'low level literacy skills affect $40 \%$ of the Australian workforce ...' (2).

In the context of this paper on adult literacy and numeracy policy, both the Productivity Commission and the AIG can in some ways be termed 'policy entrepreneurs', undertaking government commissioned research which takes the policy problem - low literacy and numeracy, as given, and legitimising a particular policy direction to address the problem. As we discuss in the next section, they both espouse a free-market, productivity-based (i.e. neoliberal) philosophy largely congruent with that of government, and thus in relation to policy as the 'allocation of values', they play a significant role. In the case of the AIG we need to add that they received significant government funding to undertake their 2010 study that represents in all probability the most expensive single research study ever undertaken into Australian adult literacy and numeracy $(\$ 500,000)$. 
Other research cited in the footnotes of the strategy document includes consultancy work by Perkins (2009) and Roberts and Wignall (2010) that was commissioned by government agencies to assist in policy formation. These consultants (and others not referenced in the NFSS) are usually unaligned to higher education institutions, and they have played a significant role in the past decade or more in helping to shape the 'products' that give form to, and guide adult literacy and numeracy policy. Perkins (2005) for example, had previously provided advice on the type of assessment tool required for the Australian adult literacy and numeracy field.

\section{'Singing off the same hymn sheet'}

We argue that the above research studies cited in the strategy are, in the words of the CEO of Skills Australia in a lead-up to the launch of strategy, 'singing off the same hymn sheet' (Canberra Institute of Technology 2010). In other words, there is a complete agreement among key stakeholders - government, industry and skills agencies, over the problem of low literacy and numeracy in the adult population, the effects this has on individuals, enterprises and the national economy, and the policies that are needed to address the problem. The 'evidence' of the extent of the problem is primarily the OECD's national and international survey data. The NFSS represents a policy that largely mirrors the research trends outlined in the opening paragraphs to this paper, that is, the privileging of 'empirical, quantitative scientific research', and in particular that undertaken and legitimised by the OECD which ideologically represents a market-driven, neoliberal agenda. The networks of national, likeminded organisations receptive to and generally constitutive of the OECD's human capital discourse include not only the government of the day, but information and advisory agencies such as the Australian Bureau of Statistics, the Productivity Commission, Skills Australia, Industry Skills Councils, and industry groups such as the AIG. These agencies are supported in their arguments through the work of a range of educational consultants who thrive on government commissioned research projects. That literacy and numeracy should be conceptualised and measured in the manner of the OECD as human capital skills integral to national and international competitiveness in a globalised economy, is unquestioned. Further, using the comparative OECD statistics, the situation is viewed as a crisis - a major deficit in the literacy and numeracy skills of Australian adults requiring national action.

The National Centre for Vocational Education Research (NCVER), funded by the federal government, is also a player, having provided designated research funds for adult literacy and numeracy research from 2002-2006, and it remains a research influence in the field. One year before the release of the NFSS, and designed to inform it, the NCVER (2011) organised a search conference entitled: 'Building the Foundations'. The two-page introduction and the first chapter to the conference papers provide a clear indication of the NCVER's perspective on the research that should underpin the strategy as key references are made to reports already outlined earlier in this paper, including those by the Productivity Commission (2010), AIG (2010) and Skills Australia (2010). Unsurprisingly, the ALL data provide the evidence that 'almost half' of Australian adults cannot function adequately (NCVER 2011, 7), and this normative crisis picture is reinforced by most of the conference papers themselves that 
involve further statistical analyses of the ALL data. On the basis of these conference papers and the NCVER's contribution, it could be argued that the NCVER is another one of those organisations singing off that same hymn sheet.

As we have seen, the key element of the research that counts in Australian adult literacy and numeracy policy, is largely global - based on the 'standardisations and normalisations' of OECD data (Jackson 2005, 769). The organisations and individuals producing and disseminating this research, at least in the Australian adult literacy and numeracy policy context, are largely outside of the higher education academy. These organisations include research and information bodies such as the NCVER, the Australian Bureau of Statistics and the Productivity Commission, and policy advocacy organisations such as Skills Australia and the ISC. In the case of the AIG, this organisation is a relatively new player in the adult literacy and research field. The AIG appears to have considerable influence in national adult literacy and numeracy policy as reflected in the funding allocated to it for research projects leading up to and beyond the NFSS (AIG 2010, 2012). Currently, the AIG is funded by the federal government to examine the return on investment (ROI) of literacy and numeracy interventions (AIG 2015). The total funding allocated to the AIG in recent years would make it the nation's leading recipient of government project funding in the field of adult literacy and numeracy. While its reports in many respects eschew the academic standards of university studies in relation to, for example, literature reviews, detailed methodologies and referencing, its reports nevertheless gain traction with government. Symbolically, the AIG reports can be seen to represent the shift mentioned earlier in the type of research that impacts on adult literacy and numeracy policy - from academics in higher education, as with the ALLP, to research undertaken by skills and industry groups that tend to reflect the prevailing market-based ideology of neoliberalism. Thus it should be of little surprise to find that the first recommendation of the AIG's major research report $(2012,78)$ states: 'Position employers at the centre of the National Foundation Skills Strategy'.

\section{Prioritising ideology over 'messy, lived practices'}

The above research cited in the NFSS presents an unproblematic linear relationship between improving literacy and numeracy levels and benefits for all, especially economic. There may well be political and pragmatic reasons for presenting the case for literacy and numeracy in this way in a policy-making environment that demands defined problems and solutions. Levin $(2005,617)$ for example, writes of the 'dynamics of government' in public policy making in which rhetoric plays a vital part, and 'what people believe to be true is much more important than what actually may be true'. To help illustrate this point in the context of this paper, some UK studies have examined literacy and numeracy in workplaces, and they contradict the view that improving literacy and numeracy skills necessarily leads to improved economic outcomes for individuals or enterprises. Meadows and Metcalf (2008), for example, in a matched comparison, longitudinal study found no employment effects for individuals after one year of participation in a literacy/numeracy programme. Similarly, Wolf et al. (2010) in another UK longitudinal study involving 53 companies, found that employers were relatively unconcerned about their workers' literacy levels, and that workers in receipt 
of a workplace basic skills programme gained no skills in the short term that would affect productivity in the companies (see also Wolf and Evans 2011). We are not suggesting, based on these studies, that there is no relationship between literacy/numeracy levels and productivity, but these studies do indicate that such a relationship is at least complex and problematic.

For more than two decades many other studies of local workplace contexts, often using ethnographic methodologies, have shown that the role of literacy and numeracy is complex. They indicate for example, that the ways in which literacy and numeracy are conceptualised, and the various claims of literacy and numeracy deficits among workers have a political dimension - they have been used to exert power over workers in various ways (e.g. Belfiore et al. 2004; Black 2004; Gee, Hull and Lankshear 1996; Gowen 1992; Hull 1997). These localised studies represent what Jackson $(2005,769)$ cited earlier in this paper refers to as the 'messy, lived practices of those who are the targets of policy'. These studies demonstrate in various ways how workers actually use literacy and numeracy in their workplace roles. In some cases, for example, literacy and numeracy are largely invisible in the sense that computer software programmes can mask them and their complexities. Hoyles et al. (2010) refer to these types of practices as 'techno-mathematical literacies'. Other recent studies, including by the authors of this paper, reinforce the view that whilst in a normative sense (such as through standardised testing) many culturally and linguistically diverse workers may be found to be lacking in English literacy and numeracy skills, their job performance in the workplace, taking into account familiarity with tasks and the role of informal mentors and mediators among their peers, can nevertheless be thoroughly proficient (Black, Yasukawa and Brown 2013a, 2013b). In other words, the English literacy and numeracy 'levels' of workers may be of little consequence for productivity.

The above studies represent what Lingard (2013) refers to as research of policy insofar as they are academic studies which problematise the issues as they attempt to uncover the perspectives of a range of stakeholders on literacy and numeracy, with the result that they may contradict the dominant discourse as represented in policy documents such as the NFSS. As we have indicated, it is perhaps understandable that policymakers seeking defined problems and solutions may experience difficulties in accommodating studies that demonstrate the issues to be complex, but the key factor preventing these studies from gaining policy traction is ideology. We have argued in this paper that the various groups and individuals providing the research which has impacted on the NFSS are 'singing off the same hymn sheet', by which we mean they share a common perspective, a common ideology (neoliberalism). They represent a dominant bloc of influential players who are uncritical promoters of the OECD-led discourse which sees literacy and numeracy as essential human capital skills in a competitive global economy. Researchers of policy are not necessarily driven by the same ideology, but there would appear to be little room for alternative ideologies in current public policy on adult literacy and numeracy in Australia, or indeed in other OECD countries (see Hamilton, Maddox and Addey 2015).

\section{Conclusion}


This paper has provided an Australian case study of adult literacy and numeracy policy to add to Lingard's (2013) work on the impact of research on education policy. The case study demonstrates the veracity of his arguments, especially in relation to 'classic distinction' between research for and research of policy. In relation to the former, we have outlined the dominant role of numbers - statistics based on OECD international surveys, and how these statistics have been used extensively in government policy (NFSS) and in the supporting research of government funded agencies such as the Australian Bureau of Statistics, the Productivity Commission, the NCVER, Skills Australia and the ISC. To these agencies we need to add the private sector in the form of the AIG, along with many private consultants, which in total forms a very powerful organisational bloc. Their dominance in Australian adult literacy and numeracy policy is due to their organisational power, as Street (2011) observes, to name and define the field. Underpinning much of their work in promoting policy reflected in the NFSS is belief in the market-driven economic ideology of neoliberalism, and as Lingard $(2013,124)$ has reminded us, public policy 'is always about the allocation of values'. For these agencies and individuals there are clear financial incentives for not looking beyond market-based problems and solutions. Directing their thinking at a distance through the regulatory function of a 'global eye' is the OECD (Lingard, Martino and Rezai-Rashti 2013, 540), which since the early 1990s has adopted literacy and numeracy as key instruments of human capital formation in a globally competitive world.

Researchers of policy may not share the same ideology, moreover, their studies, which often indicate the complexities and politics of literacy and numeracy in people's everyday lives, may contradict the dominant discourse. Hence their studies generally find little traction in public policy making processes. We conclude however, with a claim that they should. We follow the line of argument advanced by Luke $(2010,179)$ cited in the early part of this paper who promotes 'a broad, rich, multidisciplinary, quantitative and qualitative, generalizable and local canvas of research data and findings' to inform policy. While public policy is by definition political and is governed largely by prevailing dominant ideologies - neoliberalism for the past two or more decades, there is nevertheless the need to take account of local practices. In an earlier publication Luke (2003, 132), writing in relation to multilingual societies (which includes Australia), argues the need for multidisciplinary approaches to literacy policy involving 'rigorously theorised, grounded, and documented observations and analysis of the contexts for language, literacy and education'. Current educational policy responses to the global discourses of neoliberalism in Australia and other OECD countries are based on deficit models and victim blaming which fail to adequately describe the actual functions and uses of literacy and numeracy in societies, in particular in culturally and linguistically diverse societies. Following Luke (2003, 140), we claim that to move forward in both research and policy towards more inclusive models of literacy and numeracy 'is a task that will require broader, more complex forms of social science, not reductionist ones'.

\section{References}


ABS (Australian Bureau of Statistics). 2006. Adult Literacy and Life Skills Survey: Summary Results. Canberra: ABS.

AIG (Australian Industry Group). 2010. National Workforce Literacy Project: Report on Employers Views on Workplace Literacy and Numeracy Skills. North Sydney: AIG.

AIG (Australian Industry Group). 2012. When Words Fail: National Workforce Literacy Project, Final Project Report. North Sydney: AIG.

AIG (Australian Industry Group). 2015. "Building Employer Commitment to Workplace Literacy programs." http://www.aigroup.com.au/portal/site/aig/education/buildingemployer/

Atkinson, T. 2012. "Beyond Disempowering Counts: Mapping a Fruitful Future for Adult Literacies." In More Powerful Literacies, edited by L. Tett, M. Hamilton and J. Crowther, 75-87. Leicester: National Institute of Adult Continuing Education.

Australian Committee on Technical and Further Education. 1974. TAFE in Australia: Report on Needs in Technical and Further Education. Canberra: Australian Government Publishing Service.

Australian Workforce and Productivity Agency. 2013. Future Focus: National Workforce Development Strategy. Canberra: Australian Workforce and Productivity Agency.

Ball, S. J. 2006. Education Policy and Social Class: The Selected Works of Stephen J. Ball. London: Routledge.

Ball, S. J. 2012. Global Education Inc.: New Policy Networks and the Neo-Liberal Imaginary. London: Routledge.

Belfiore, M., T. Defoe, S. Folinsbee, J. Hunter, and N. Jackson. 2004. Reading Work: Literacies in the New Workplace. Mahwah, NJ: Lawrence Erlbaum.

Black, S. 2004. "Whose Economic Wellbeing? A Challenge to Dominant Discourses on the Relationship Between Literacy/Numeracy Skills and (Un)Employment." Literacy and Numeracy Studies 13 (1): 7-18.

Black, S., and K. Yasukawa. 2014a. "Level 3: Another Single Measure of Adult Literacy and Numeracy." The Australian Educational Researcher 41 (2): 125-138.

Black, S., and K. Yasukawa. 2014b. "The Literacy Myth Continues: Adapting Graff's Thesis to Contemporary Policy Discourses on Adult 'Foundation Skills' in Australia." Critical Studies in Education 55 (2): 213-228.

Black, S., K. Yasukawa, and T. Brown. 2013a. Investigating the 'Crisis': Production Workers' Literacy and Numeracy Practices. Adelaide: National Centre for Vocational Education Research.

Black, S., K. Yasukawa, and T. Brown. 2013b. "The Literacy and Numeracy Crisis in Australian Workplaces: Discursive Rhetoric vs. Production Floor Realities." Journal of Education and Work doi: 10.1080/13639080.2013.854875

Canberra Institute of Technology. 2010. "Literacy and Numeracy are Holding Australia Back."

http://cit.edu.au/partnerships/industry_connection/2010_june/literacy_and_numeracy_hold ing_australia_back

Connell, R. 2013. "The Neoliberal Cascade and Education: An Essay on the Market Agenda and Its Consequences." Critical Studies in Education 54 (2): 99-112. 
Coulombe, S., J. Tremblay, and S. Marchland. 2004. Literacy Scores, Human Capital and Growth Across 14 OECD Countries. Ottawa: Statistics Canada.

Cumming, J., and J. Morris. 1991. Working Smarter. Canberra: Department of Employment, Education and Training.

Dawkins, J., and C. Holding. 1987. Skills for Australia. Canberra: Department of Employment, Education and Training.

DEET (Department of Employment, Education and Training). 1991. Australia's Language: The Australian Language and Literacy Policy. Canberra: DEET.

Gardner, A., M. Hamilton, C. Pinsent-Johnson, R. Darville, and T. Atkinson. 2010. "Tensions Between Policy, Practice and Theory: International Perspectives on Adult Literacy." In Conference Proceedings, Canadian Association for the Study of Adult Education (CASAE), 349-353. Montreal: CASAE.

Gee, J., G. Hull, and C. Lankshear. 1996. The New Work Order: Behind the Language of the New Capitalism. Sydney: Allen and Unwin.

Gordon, I., J. Lewis, and R. Young. 1977. "Perspectives on Policy Analysis." Public Administration Bulletin 25: 26-35.

Gowen, S. 1992. The Politics of Workplace Literacy: A Case Study. New York: Teachers College Press.

Grek, S. 2013. "Expert Moves: International Comparative Testing and the Rise of Expertocracy." Journal of Education Policy 28 (5): 695-709.

Hamilton, M. 2001. "Privileged Literacies: Policy, Institutional Process and the Life of IALS." Language and Education 15 (2): 178-196.

Hamilton, M. 2011. "Unruly Practices: What a Sociology of Translation Can Offer to Educational Policy Analysis.” Educational Philosophy and Theory 43 (7): 55-75.

Hamilton, M. 2012. Literacy and the Politics of Representation. London: Routledge.

Hamilton, M. 2014. "Global, Regional and Local Influences on Adult Literacy Policy in England." Globalisation, Societies and Education 12 (1): 110-126.

Hamilton, M., and D. Barton. 2000. "The International Adult Literacy Survey (IALS): What Does It Really Measure?” The International Review of Education 46 (5): 377-389.

Hamilton, M., and K. Pitt. 2011. "Challenging Representations: Constructing Literacy Across Three Decades of UK Policy.” Reading Research Quarterly 46 (4): 350-373.

Hamilton, M., B. Maddox, and C. Addey, eds. 2015. Literacy as Numbers: Researching the Politics and Practices of International Literacy Assessment. Cambridge: Cambridge University Press.

Hoyles, C., R. Noss, P. Kent, and A. Bakke. 2010. Improving Mathematics at Work: The Need for Techno-Mathematical Literacies. London: Taylor \& Francis.

Hull, G. 1997. Changing Work, Changing Workers: Critical Perspectives on Language, Literacy and Skills. New York: State University of New York.

ISC (Industry Skills Councils). 2011. No More Excuses: An Industry Response to the Language, Literacy and Numeracy Challenge. Canberra: Australian Government.

Jackson, N. 2005. "Adult Literacy Policy: Mind the Gap." In International Handbook of Educational Policy, edited by N. Bascia, A. Cumming, A Datnow, K. Leithwood, and D. Livingstone, 763-778. Dordrecht: Springer. 
Jablonka, E. 2015. "The Evolvement of Numeracy and Mathematical Literacy Curricula and the Construction of Hierarchies of Numerate or Mathematically Literate Subjects." ZDM Mathematics Education 47 (4): 599-609.

Kell, C. 2001. "Ciphers and Currencies: Literacy Dilemmas and Shifting Knowledges." Language and Education 15 (2-3): 197-211.

Legrand, T., and P. Vas. 2014. "Framing Policy Analysis of OECD and Australian VET Interaction: Two Heuristics of Policy Transfer." Journal of Comparative Policy Analysis 16 (3): 230:248.

Levin, B. 2005. "Improving Research-Policy Relationships: The Case of Literacy." In International Handbook of Educational Policy, edited by N. Bascia, A. Cumming, A Datnow, K. Leithwood, and D. Livingstone, 613-628. Dordrecht: Springer.

Lingard, B. 2010. "Policy Borrowing, Policy Learning: Testing Times in Australian Schooling." Critical Studies in Education 51 (2): 129-147.

Lingard, B. 2011. "Policy as Numbers: Ac/counting For Educational Research." The Australian Educational Researcher 38 (4): 355-382.

Lingard, B. 2013. "The Impact of Research on Education Policy in an Era of EvidenceBased Policy." Critical Studies in Education 54 (2): 113-131.

Lingard, B., W. Martino, and G. Rezai-Rashti. 2013. "Testing Regimes, Accountabilities and Education Policy: Commensurate Global and National Developments." Journal of Education Policy 28 (5): 539-556.

Lo Bianco, J. 2001. From Policy to Anti-Policy: How Fear of Language Rights Took PolicyMaking Out of Community Hands." In Australian Policy Activism in Language and Literacy, edited by J. Lo Bianco, and R. Wickert, 13-44. Melbourne: Language Australia.

Lo Bianco, J., and R. Wickert, eds. 2001. Australian Policy Activism in Language and Literacy. Melbourne: Language Australia.

Long, P. 1989. Literacy For Productivity: A Study of Adult Literacy in the Workplace. Canberra: Australian Advisory Council on Language and Multicultural Education.

Luke, A. 2003. "Literacy and the Other: A Sociological Approach to Literacy Research and Policy in Multilingual Societies.” Reading Research Quarterly 38 (1): 132-141.

Luke, A. 2010. "Documenting Reproduction and Inequality: Revisiting Jean Anyon's 'Social class and school knowledge'.” Curriculum Inquiry 40 (1): 167-182.

Meadows, P., and H. Metcalf. 2008. Does Literacy and Numeracy Training for Adults Increase Employment and Employability? Evidence From the Skills for Life Programme in England." Industrial Relations Journal 39 (5): 254-369.

NCVER (National Centre for Vocational Education Research). 2011. Building the Foundations: Outcomes From the Adult Language, Literacy and Numeracy Search Conference, Discussion Paper. Adelaide: NCVER.

OECD (Organisation for Economic Co-operation and Development) and Statistics Canada. 2005. Learning a Living: First Results From the Adult Literacy and Life Skills Survey. Paris and Ottawa: OECD \& Statistics Canada.

Perkins K. 2005. Reframe, Rename, Revitalise: Future Directions for the Language, Literacy and Numeracy National Reporting System. Adelaide: National Centre for Vocational Education Research. 
Perkins, K. 2009. Adult Literacy and Numeracy: Research and Future Strategy. Adelaide: National Centre for Vocational Education Research.

Pinsent-Johnson, C. 2015. "From an International Adult literacy Assessment to the Classroom: How test development Methods are Transposed into Curriculum." In Literacy as Numbers: Researching the Politics and Practices of International Literacy Assessment, edited by M. Hamilton, B. Maddox, and C. Addey, 187-206. Cambridge: Cambridge University Press.

Productivity Commission. 2010. Links Between Literacy and Numeracy Skills and Labour Outcomes. Canberra: Productivity Commission.

Rizvi, P., and B. Lingard. 2010. Globalizing Education Policy. London: Rutledge.

Roberts, A., and L. Wignall. 2010. Briefing on Foundation Skills for the National VET Equity Advisory Council. Melbourne: NVEAC.

Rubenson, K., and J. Walker. 2011. "An Examination of the IALS and Its Influence on Adult Literacy in Canada." Paper presented at IALS (International Adult Literacy Survey) Its Meaning and Impact for Policy and Practice. Banff, AB, October 23-25.

Ryan, R. 2011. How VET Responds: A Historical Perspective. Adelaide: National Centre for Vocational Education Research.

SCOTESE (Standing Council on Tertiary Education, Skills \& Employment). 2012. National Foundation Skills Strategy for Adults. Canberra: SCOTESE.

Sellar, S., and B. Lingard. 2013. "The OECD and Global Governance in Education." Journal of Education Policy 28 (5): 710-725.

Skills Australia. 2010. Australian Workforce Futures: A National Workforce Development Strategy. Canberra: Commonwealth of Australia.

Street, B. 1998. "Literacy, Economy and Society." Literacy Across the Curriculum 12 (3): 815.

Street, B. 2011. "Literacy Inequalities in Theory and Practice: The Power to Name and Define." International Journal of Educational Development 31 (6): 577-579.

Tett, L. 2014. "Comparative Performance Measures, Globalising Strategies and Literacy Policy in Scotland." Globalisation, Societies and Education 12 (1): 127-142.

Tsatsaroni, A., and J. Evans. 2014. "Adult Numeracy and the Totally Pedagogised Society: PIAAC and Other International Surveys in the Context of Global Educational policy on Lifelong Learning." Educational Studies in Mathematics 87 (2): 167-186.

Walker, J., and K. Rubenson. 2014. "The Media Construction of an Adult Literacy Agenda in Canada." Globalisation, Societies and Education 12 (1): 143-1.

Wickert, R. 1989. No Single Measure: A Survey of Australian Adult Literacy. Canberra: Department of Employment, Education and Training.

Wickert, R. 2001. "Policy Activism and Processes of Policy Production: Adult Literacy in Australia." In Australian Policy Activism in Language and Literacy, edited by J. Lo Bianco, and R. Wickert, 75-91. Melbourne: Language Australia.

Wolf, A., L. Aspin, E. Waite, and K. Ananiadou. 2010. "The Rise and Fall of Workplace Basic Skills Programmes: Lessons for Policy and Practice." Oxford Review of Education 36 (4): 385-405.

Wolf, A., and K. Evans. 2011. Improving Skills at Work. London: Routledge. 
Yasukawa, K., and J. Evans. 2015. "Critically Reading the OECD Survey of Adult Skills." In Proceedings of the $8^{\text {th }}$ International Mathematics, Education and Society Conference, edited by S. Mukhopadhyay, and B. Greer, 1008-1021. Portland State University, June 2126. http://mescommunity.info/MES8ProceedingsVol3.pdf 